\title{
Purification and characterization of a serine protease (CESP) from mature coconut endosperm
}

\author{
Leelamma M Panicker*1, Rajamma Usha², Samir Roy and \\ Chhabinath Mandal ${ }^{3}$
}

Address: ${ }^{1}$ National Institutes of Health, Building 10, Room 8C 209, Bethesda, Maryland-20892, USA, ${ }^{2}$ Manovikas Biomedical Research \& Diagnostic Centre, 482 Madudah, Plot I-24, Sector-J, EM Bypass, Kolkata-700 107, India and ${ }^{3}$ DOEACC Centre (Bioinformatics Division, Jadavpur University), 4 Raja SC Mullick Road Kolkata-700032, India

Email: Leelamma M Panicker* - leelammaj@niddk.nih.gov; Rajamma Usha - usha_iicb@yahoo.com; Samir Roy - samirroy_iicb@yahoo.com; Chhabinath Mandal - cnmandal@iicb.res.in

* Corresponding author

Published: 9 May 2009

BMC Research Notes 2009, 2:8I doi:10.1186/1756-0500-2-81
Received: 18 September 2008

Accepted: 9 May 2009

This article is available from: http://www.biomedcentral.com/1756-0500/2/81

(C) 2009 Panicker et al; licensee BioMed Central Ltd.

This is an Open Access article distributed under the terms of the Creative Commons Attribution License (http://creativecommons.org/licenses/by/2.0), which permits unrestricted use, distribution, and reproduction in any medium, provided the original work is properly cited.

\begin{abstract}
Background: In plants, proteases execute an important role in the overall process of protein turnover during seed development, germination and senescence. The limited knowledge on the proteolytic machinery that operates during seed development in coconut (Cocos nucifera L.) prompted us to search for proteases in the coconut endosperm.

Findings: We have identified and purified a coconut endosperm protease (CESP) to apparent homogeneity. CESP is a single polypeptide enzyme of approximate molecular mass of $68 \mathrm{kDa}$ and possesses $\mathrm{pH}$ optimum of 8.5 for the hydrolysis of BAPNA. Studies relating to substrate specificity and pattern of inhibition by various protease inhibitors indicated that CESP is a serine protease with cleavage specificity to peptide bonds after arginine. Purified CESP was often autolysed to two polypeptides of $41.6 \mathrm{kDa}(\mathrm{CESPI})$ and $26.7 \mathrm{kDa}$ (CESP2) and is confirmed by immunochemistry. We have shown the expression of CESP in all varieties of coconut and in all stages of coconut endosperm development with maximum amount in fully matured coconut.

Conclusion: Since the involvement of proteases in the processing of pre-proteins and maintenance of intracellular protein levels in seeds are well known, we suspect this CESP might play an important role in the coconut endosperm development. However this need to be confirmed using further studies.
\end{abstract}

\section{Background}

Proteases, being major regulatory enzymes, play a prominent house-keeping role in the cell physiology of all living systems. In plants, these enzymes execute an important role in the overall process of protein turnover in all stages of its life [1-6]. Seed development is an intricate process by which the seeds synthesize and store extensively a number of proteins, carbohydrates and lipids for subse- quent use during seedling growth. Different types of proteases, which are active during seed development, are very scarcely studied, even though their importance in proteolytic processing of pre-proteins and regulation of intracellular protein levels are very well identified [7].

Coconut (Cocos nucifera L.), which belongs to the family of Palmae, is widely distributed in tropical countries. The 
properties of protein extracted from desiccated coconut showed that its protein content is comparable to soy protein in terms of composition and amount [8]. However, the research pertaining to the biochemical aspects of endosperm development are still lacking except few studies, which shows the chemical constituents of coconut endosperm and biochemical changes happening during the germination of coconut seeds suggests a metabolically active stage during seed development [9-14]. While investigating the presence of proteases in the developing endosperm, we have identified three types of these enzymes [15]. In the present paper, we report the purification and characterization of a serine protease from mature coconut endosperm (CESP), which possessed the BAPNA hydrolyzing activity. We also detected CESP in coconut endosperm during seed development and in different varieties of coconut using immunochemistry.

\section{Methods}

For the purification of CESP, eighty grams of fully matured coconut kernel was used and the entire purification procedure was carried out at $4{ }^{\circ} \mathrm{C}$ and the total enzyme activity and protein concentration at each level of purification was estimated.

\section{(i) Preparation of crude extract}

Kernel was cut into small pieces, frozen in liquid nitrogen, powdered, homogenized in four volumes of ice-cold 20 mM TBS at pH 7.8 containing $150 \mathrm{mM} \mathrm{NaCl}$ (buffer A) using a wet grinder, strained through muslin cloth, centrifuged at $14,400 \times g$ for 25 minutes, removed the upper creamy layer of fat and the clear crude extract was obtained by passing through glass wool.

\section{(ii) Ammonium sulfate fractionation and gel filtration}

The crude extract was subjected to ammonium sulfate fractionation (30-60\%) and the pellet was dissolved in a minimum volume of ice-cold buffer $A$ and then loaded on to a Sephadex G-200 gel filtration column $(105 \mathrm{~cm} \times 2.3$ $\mathrm{cm}$ ) equilibrated with the buffer A. The fractions (25 to $35)$ with high specific activity were pooled.

\section{(iii) Phenyl-Sepharose Chromatography}

Solid ammonium sulfate was added to the pooled fractions from the above step to yield a final concentration of $0.4 \mathrm{M}\left(\mathrm{NH}_{4}\right)_{2} \mathrm{SO}_{4}$ and was then subjected to phenylSepharose column $(5 \mathrm{~cm} \times 1.6 \mathrm{~cm})$ pre-equilibrated with buffer A containing $0.4 \mathrm{M}\left(\mathrm{NH}_{4}\right)_{2} \mathrm{SO}_{4}$. The bound enzyme was eluted using a gradient of buffer A containing $0.4 \mathrm{M}$ to $0.0 \mathrm{M}\left(\mathrm{NH}_{4}\right)_{2} \mathrm{SO}_{4}$. Fractions of $1 \mathrm{ml}$ with high protease activity were pooled and dialyzed against buffer $\mathrm{A}$ without $150 \mathrm{mM} \mathrm{NaCl}$ (buffer B).

\section{(iv) DEAE-cellulose Chromatography}

The pooled fractions were passed through DEAE-cellulose column $(4.5 \mathrm{~cm} \times 1.5 \mathrm{~cm})$ equilibrated with buffer $\mathrm{B}$. The enzyme was eluted using a gradient of $0-0.5 \mathrm{M} \mathrm{NaCl}$ in buffer $\mathrm{B}$ and the fractions with high protease activity were concentrated by dialyzing against buffer B using Centricon 10 .

\section{(v) Arginine-Sepharose Chromatography}

The dialysate from the previous step was loaded on this column $(7 \mathrm{~cm} \times 0.9 \mathrm{~cm})$ equilibrated with buffer B and the bound enzyme was eluted using a gradient of $(0-0.3)$ $\mathrm{M} \mathrm{NaCl}$ in the same buffer.

\section{(vi) Biogel P60 gel filtration chromatography}

Selected fractions from the previous step was pooled and concentrated to a volume of $0.5 \mathrm{ml}$ and subjected to Biogel P60 column $(50 \mathrm{~cm} \times 1 \mathrm{~cm})$, equilibrated with buffer A.

\section{Enzyme activity assay}

Protease activity was assayed during the purification process using a synthetic peptide No-Benzoyl DL-arginine pnitroanilide (BAPNA) as the substrate. The reaction mixture contained $100 \mathrm{mM}$ Tris $\mathrm{HCl}(\mathrm{pH}$ 8.5), enzyme solution and $0.5 \mathrm{mM}$ substrate in a total volume of $500 \mu \mathrm{l}$. Reaction was carried out at $37^{\circ} \mathrm{C}$ for one hour and stopped by an addition of $500 \mu \mathrm{l}$ of ethanol. The liberated colored p-nitroaniline was measured at $405 \mathrm{~nm}$ using spectrophotometer (Hitachi U 2000). One unit of enzyme activity (EU) was defined as $1 \mu$ mole of $p$-nitroaniline liberated per hour under the conditions of assay. The enzyme activity was calculated using a $p$-nitroaniline molar extinction coefficient of $10,500 \mathrm{M}^{-1} \mathrm{~cm}^{-1}$ at $405 \mathrm{~nm}$.

\section{Preparation of Antibody}

Protein bands corresponding to the CESP proteolytic products of $26.7 \mathrm{kDa}$ (CESP2) and $41.6 \mathrm{kDa}$ (CESP1) were cut from the gel after SDS-PAGE and eluted using electro-eluter from Bio-Rad. Two rabbits were immunized independently (rabbit 1-26.7 kDa, rabbit 2-41.6 kDa) by giving three subcutaneous injections, for a total of $700 \mu \mathrm{g}$ proteins into respective rabbits. After 7 days of the booster dose, rabbits were bled through the ear vein and tested for the presence and specificity of antibody by immuno-diffusion [16] and immuno-blot analysis [17]. Total IgG from the immune sera directed against $26.7 \mathrm{kDa}$ polypeptide was isolated by $33 \%$ ammonium sulphate fractionation and DEAE cellulose ion-exchange chromatography.

\section{Gel Electrophoresis}

SDS-PAGE was carried out as described by Laemmli [18] on $12 \%$ polyacrylamide gel and non-denaturing PAGE on $7 \%$ polyacrylamide gel. Western blot analysis was done as described by Towbin [17] using immunized serum 1: 200. 
The detection of proteolytic activity on $12 \%$ polyacrylamide gel containing SDS and $0.25 \%$ gelatin was carried out as described by Heussen and Dowdle [19] except that Triton X-100 (1\%) in Tris buffer pH 8.5 used for re-naturation of the gels. Gels were then incubated in the same buffer with out Triton X-100 for over night at room temperature.

\section{Other methods}

Absorbance at $280 \mathrm{~nm}$ was used for monitoring the protein during chromatographic elution. Total proteins in the pooled fractions were estimated using the Coomassie dyebinding assay [20]. Arginine-Sepharose and IgG-Sepharose affinity matrices prepared using cyanogen bromide method [21].

For the detection of CESP in different varieties (endosperms stored at $-80^{\circ} \mathrm{C}$ about an year) and different developmental stages of coconut (fresh), crude extract was prepared from the endosperm of the coconuts collected from the identified palms.

\section{Results and Discussion}

\section{Purification of CESP from the coconut endosperm}

Purification steps of CESP are presented in Fig. 1 (A-D) and the summary of the whole process is tabulated in Table 1 . The protease was purified approximately 41 fold by ammonium sulphate fractionation and gel filtration (Table 1). Later steps yielded only marginal increase in the fold purification leading to an overall recovery of 0.183 $\mathrm{mg}$ of protein with a specific activity of $14.42 \mathrm{EU} / \mathrm{mg}$ from $80 \mathrm{~g}$ of tissue. The enrichment of the CESP after the entire purification procedure resulted in 515-fold.

The Coomassie blue stained polyacrylamide gel from various stages of purification (Fig. 2(I)) showed that by DEAE step almost all the contaminating proteins were removed. A protein at $68 \mathrm{kDa}$ region was the most prominent one observed. Two additional minor bands observed at 41.6 and $26.7 \mathrm{kDa}$ in the last step of purification may be a result of autolysis, which could be removed again by gel filtration on Biogel P60 (Fig. 1E). In the absence of other proteins and endogenous substrates, the purified CESP might have undergone self-degradation. This was observed previously in other plant serine proteases [2225].

\section{Homogenity and molecular size of the purified CESP}

The SDS-PAGE analysis of the purified CESP immediately after Biogel P60 gel filtration step showed a single band at $68 \mathrm{kDa}$ region (Fig. 2(II) A) and under non-denaturing conditions, gave a single broad protein band as shown in Fig. 2(II) B.
The molecular weight $68 \mathrm{kDa}$ as determined by SDSPAGE analysis (Fig. 2(II) B) and $69.5 \mathrm{kDa}$ by gel filtration on Sephadex G-100 (see Additional file 1, Fig S1) indicate that CESP is a single polypeptide protease. The molecular weights of the serine proteases of cucumisin family and the latex peptidases also have been reported to be single polypeptide enzymes with molecular weight ranging between 60 and $80 \mathrm{kDa}$ [25-28]. Molecular weights of the minor protein bands were estimated as $41.6 \mathrm{kDa}$ and 26.7 $\mathrm{kDa}$ using SDS-PAGE analysis, suggesting that these might have arrived from the $68 \mathrm{kDa}$ CESP.

\section{Substrate specificity and $\mathrm{pH}$ dependence of the purified CESP}

The BAPNA hydrolysis was linear with time and increasing concentration of the enzyme (Figs. 3A, B). Similar to most of the serine proteases [26-29] the optimum enzyme activity using BAPNA was found to be at pH 8.5, above and below that $\mathrm{pH}$ the activity decreased (Fig. 3C). Km value of the enzyme was calculated as $0.2 \mathrm{mM}$ for BAPNA (Fig. 3D), which is close to other serine proteases. Among the seven substrates tested, CESP hydrolyzed rapidly those that have arginine residue at the C-terminal side of the peptide bond (Table 2). This indicates that enzyme may be a trypsin-like protease. It also slowly hydrolysed SucAla-Ala-Phe-MCA implying that CESP also has some chymotrypsin-like activity. However, the enzyme did not hydrolyse another substrate for chymotrypsin, Suc-LeuLeu-Val-Tyr-MCA. The substrate specificity must be studied further to verify these conclusions, but similar specificity has been observed for some serine proteases like trypsin and other plant proteases like cuminisin and Q-SP $[27,28]$.

\section{The effect of protease inhibitors, metal ions and complexes on CESP}

Trypsin protease inhibitors TLCK and antipain, and chymotrypsin inhibitor TPCK strongly inhibited hydrolysis of BAPNA (Table 3). Other serine protease inhibitors Benzamidine and PMSF inhibited 50 and 43\% respectively. However trypsin inhibitors, Aprotinin and SBTI did not affect the enzyme activity. Inhibition of CESP by a chymotrypsin inhibitor TPCK supports the observation on the substrate specificity that the protease may have some chymotrypsin-like activity. Pepstatin, metal ions, chelators and sulfhydryl-blocking agents did not inhibit the enzyme (Table 3). These results indicate that CESP is a serine protease [27].

\section{Zymogram analysis of purified CESP on gelatin polyacrylamide gel}

Zymogram analysis of the purified protease showed gelatin hydrolysis at positions that correspond to 68 and 26.7 $\mathrm{kDa}$ protein bands (Fig 3E). As the zymogram of the of crude extract prepared from fresh coconut, showed only 

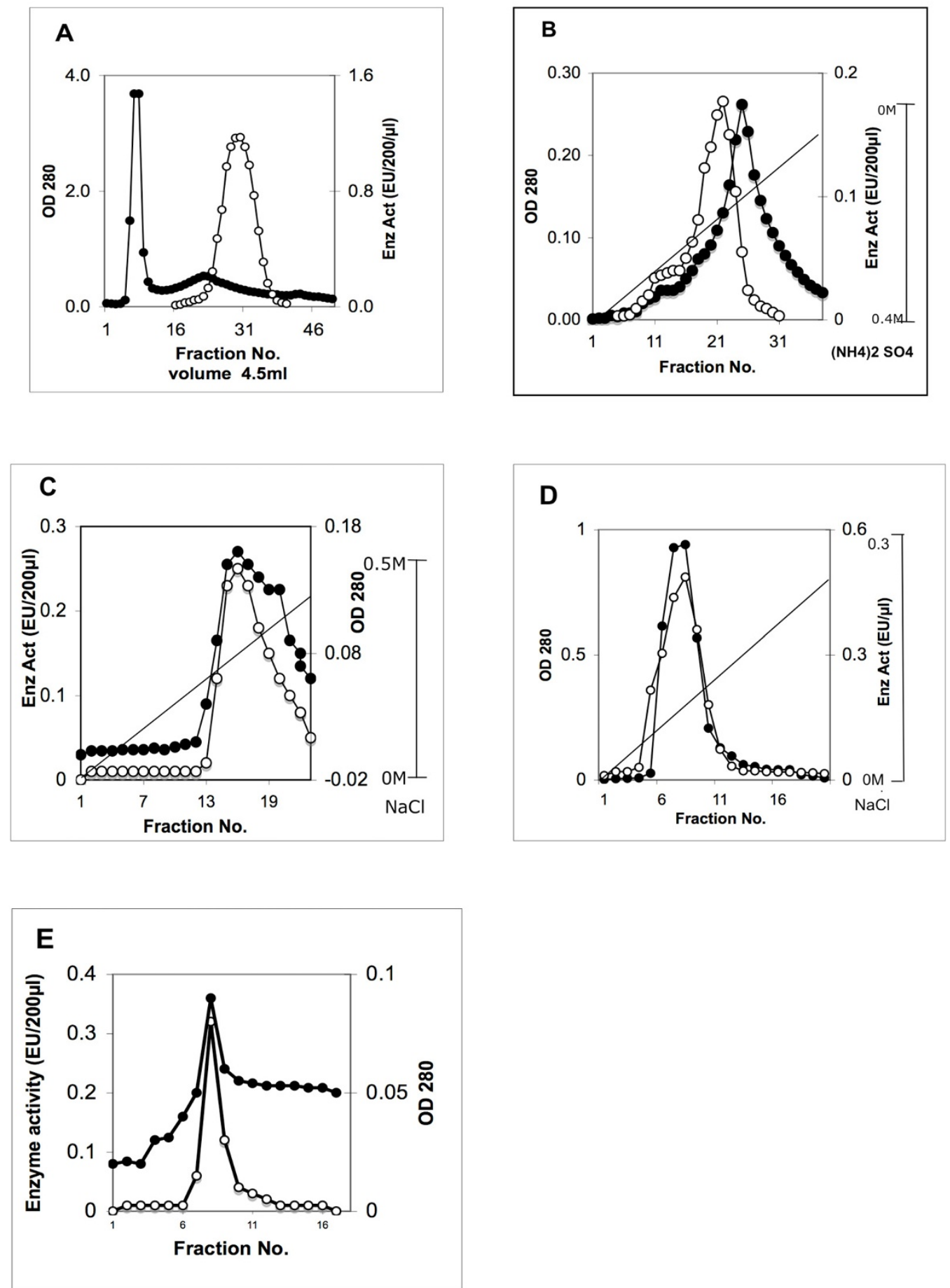

\section{Figure I}

Purification of the protease (CESP) from coconut endosperm. The crude extract after ammonium sulfate fractionation was subjected to (A), Gel filtration chromatography; (B), Phenyl sepharose affinity chromatography; (C), DEAE-cellulose chromatography; (D), Arginine-Sepharose affinity chromatography; (E), Biogel P60 gel filtration chromatography. "Black circles" represents the absorbance of the protein at $280 \mathrm{~nm}$ and "white circles" represents the protease activity in Enzyme Units $(E U)$. The straight line in figures $B, C$ and $D$ represents the gradient of salt concentration used for eluting the protease. 
Table I: Summary of Purification of CESP from coconut kernel.

\begin{tabular}{|c|c|c|c|c|c|}
\hline Steps & Total Protein (mg) & Total Activity (EU) & Specific Activity (EU/mg) & Yield (\%) & Fold Purification \\
\hline I. Crude extract & 1380 & 38.17 & 0.028 & 100 & 1 \\
\hline 2. Sephadex G 200 & 16.51 & 19.09 & 1.16 & 50.02 & 41.42 \\
\hline 3. Phenyl-Sepharose & 1.36 & 5.95 & 4.37 & 15.57 & 156.1 \\
\hline 4. DEAE-Cellulose & 0.986 & 4.86 & 4.93 & 12.74 & I76.I \\
\hline 5. Arginine-Sepharose & 0.260 & 3.21 & 12.37 & 8.43 & 441.8 \\
\hline 6. Biogel P60 & 0.183 & 2.59 & 14.42 & 6.78 & 515 \\
\hline
\end{tabular}

one band at $68 \mathrm{kDa}$ [15], it is possible that $26.7 \mathrm{kDa}$ band is an autolysed product of the protease that has retained protease activity. The cleavage of gelatin into small peptides indicates CESP to be an endopeptidase, which can cleave the protein substrate at different locations to generate small peptides [26-29].

\section{Characterization of the polyclonal antisera raised in} rabbits against (4I.6 kDa and $26.7 \mathrm{kDa}$ ) polypeptides

Polyclonal antisera were raised in rabbits against the 41.6 kDa (CESP1) and 26.7 kDa (CESP2) polypeptides. Specificity against peptides was verified. Western blot analysis of step purification using these antisera recognized $68 \mathrm{kDa}$ protein (see Additional file 1, Fig. S2 and Fig S3), Analysis of the purified CESP after storage for one week, gave two distinct bands in each case, one represented the intact CESP and the other represented either $41.6 \mathrm{kDa}$ or 26.7 $\mathrm{kDa}$ polypeptides corresponding to CESP1 and CESP2 depending on the antisera used (see Additional file 1, Fig. S4).
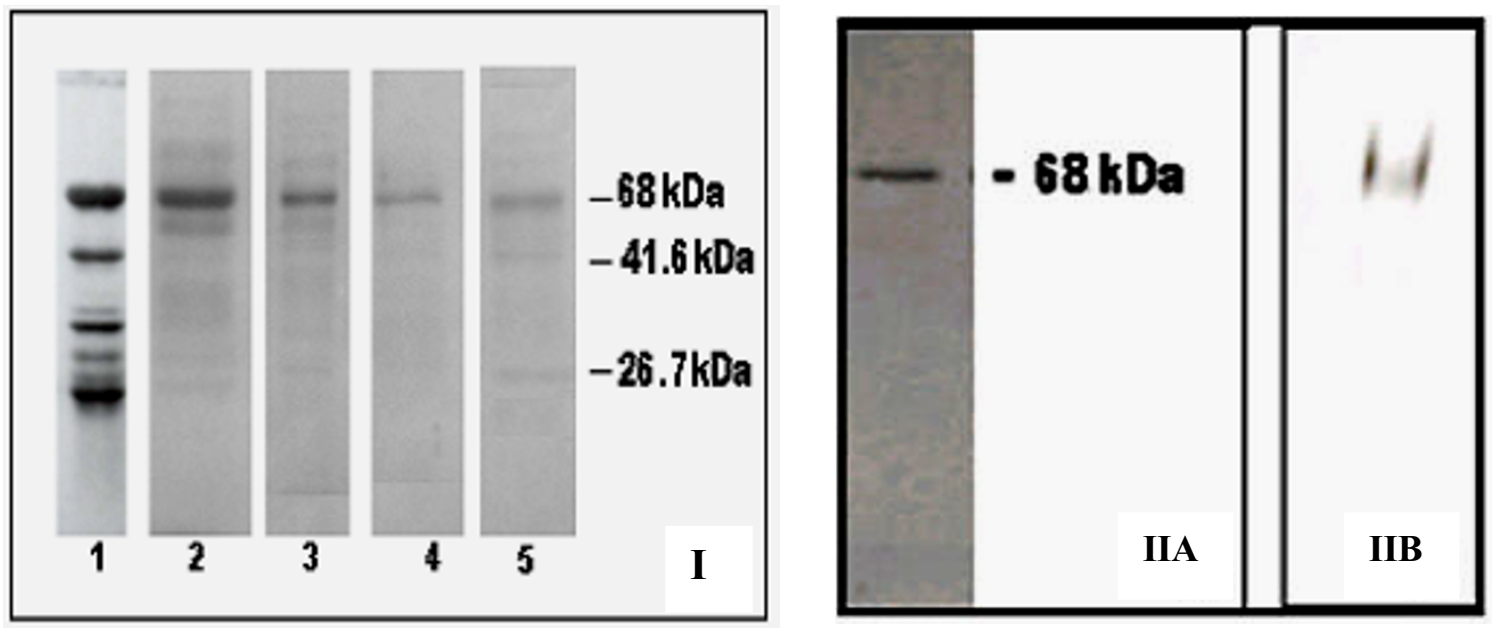

Figure 2

Analysis of the protein by SDS/PAGE during enzyme purification and testing of the homogeneity of the purified CESP. 2(I): Proteins from different stages of the purification were analyzed by $12 \%$ SDS-PAGE. Different lanes were loaded with pooled proteins from different steps. Lane I, crude homogenate ( $8 \mu \mathrm{g})$; Lane 2, gel filtration (4 $\mu$ g); Lane 3, PhenylSepharose $(2.5 \mu \mathrm{g})$; Lane 4, DEAE-cellulose $2 \mu \mathrm{g}$; Lane 5, Arginine Sepharose $(2 \mu \mathrm{g})$. 2(II): Analysis of the purified protease from Biogel P60 was carried out both by (A) SDS/PAGE on I $2 \%$ polyacrylamide gel (I.8 $\mu \mathrm{g})$ and (B) nondenaturing PAGE on $7 \%$ polyacrylamide gel $(2 \mu \mathrm{g})$. 


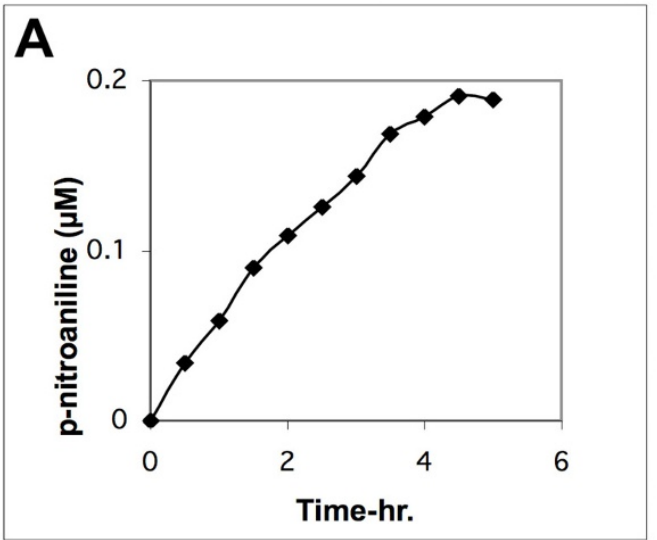

\section{B}
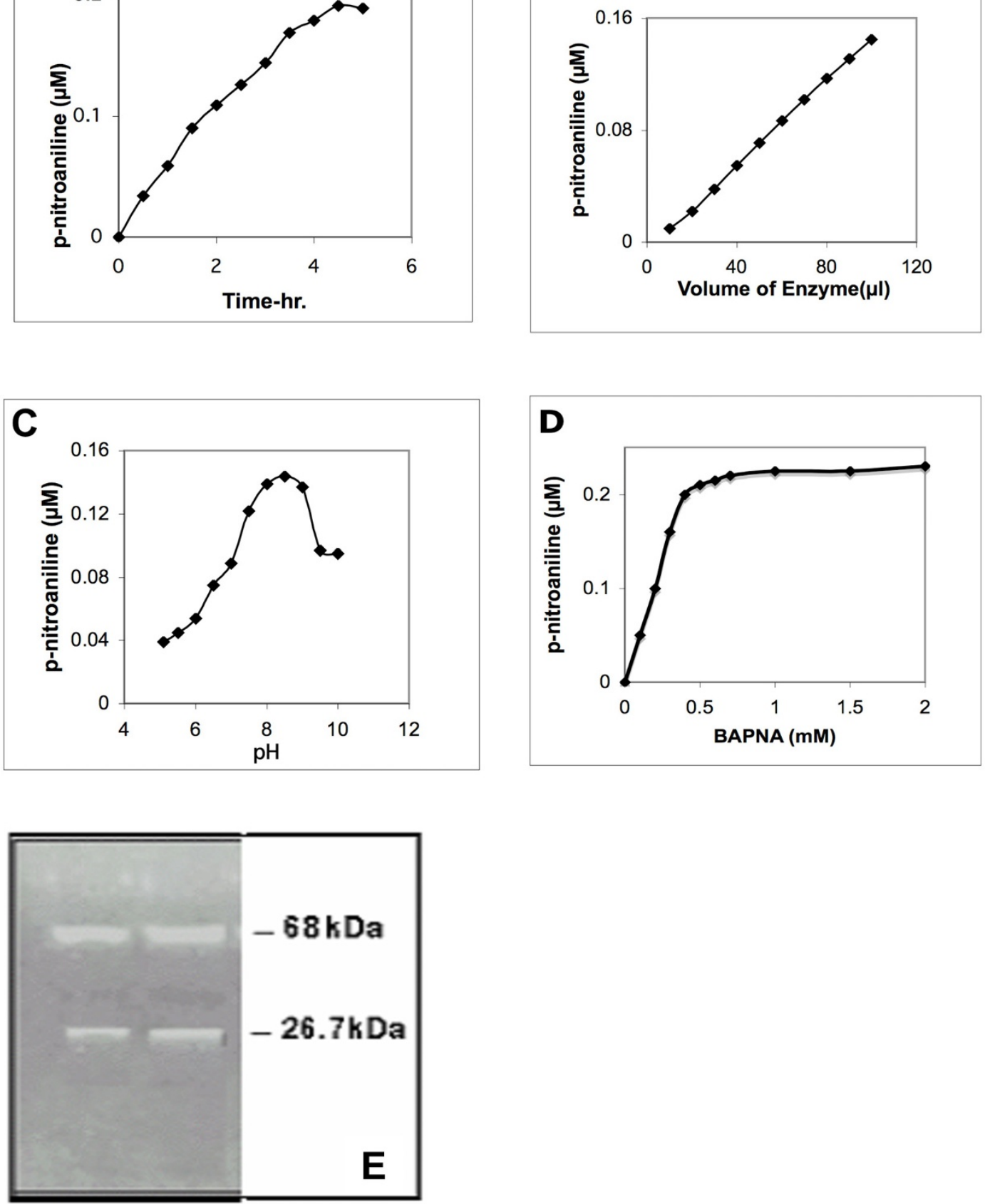

\section{Figure 3}

Profile of BAPNA hydrolysis by the purified enzyme. (A) $50 \mu$ l of purified enzyme was assayed at pH 8.5 for BAPNA hydrolysis for different time periods up to 5 hrs using 50 mM BAPNA substrate (B) BAPNA hydrolysis was carried out for I hour with increasing volume of purified enzyme. (C) $\mathrm{pH}$ optimum of BAPNA hydrolysis by the purified CESP was studied in $100 \mathrm{mM}$ buffers of varying $\mathrm{PH}$. The buffers used were: Na Ac (5.I), MES (5.5, 6.0), PIPES (6.5, 7), Tris HCl (7.5 to 9) and CAPS $(9.7,10)$. (D) Measurement of Michaelis-Menten constant $(\mathrm{Km})$ : $p$-nitroaniline liberated was measured by varying substrate concentrations. Conditions of reactions are same as mentioned earlier. (E) SDS/PAGE zymogram analysis of the purified CESP, $2 \mu \mathrm{g}$ ( ${ }^{\text {st }}$ lane $) \& 3 \mu \mathrm{g}$ ( $2^{\text {nd }}$ lane $)$ of the purified CESP after storage for one week. 
Table 2: Hydrolysis of fluorogenic peptide substrate by the purified CESP

\begin{tabular}{lcc}
\hline Fluorogenic Substrates & $\begin{array}{c}\text { Concentration } \\
\text { used }(\mathbf{m M})\end{array}$ & $\begin{array}{c}\text { Relative Fluorescence } \\
\text { Intensity }\end{array}$ \\
\hline Boc-Leu-Arg-Arg-MCA & 0.05 & 698.00 \\
\hline Boc-Val-Pro-Arg-MCA & 0.05 & 583.50 \\
\hline Suc-Ala-Ala-Phe-MCA & 0.05 & 120.70 \\
\hline Suc-Leu-Leu-Val-Tyr-MCA & 0.05 & 0.060 \\
\hline Boc-Phe-Ser-Arg-MCA & 0.05 & 625.85 \\
\hline Bz-Phe-Val-Arg-BNA & 0.05 & 422.90 \\
\hline Bz-Leu-Leu-Glu-BNA & 0.05 & 0.020 \\
\hline
\end{tabular}

$100 \mu \mathrm{l}$ of reaction mixture containing $10 \mu \mathrm{l}$ of purified enzyme, $0.05 \mathrm{mM}$ of the substrates and $100 \mathrm{mM}$ Tris $\mathrm{HCl} \mathrm{pH} 8.5$ was incubated at $37^{\circ} \mathrm{C}$ for $30 \mathrm{~min}$ and the reaction was stopped by the addition of $1.9 \mathrm{ml}$ of ethanol. The product of hydrolysis was measured spectroflourimetrically (for AMC-Exc-380 nm, Em-460 nm and for $\beta$ NA-Exc-335 nm, Em-410 nm).

Zymogram and western blot analysis of the purified CESP after PAGE on gelatin gels

CESP from various steps of purification were subjected to electrophoresis on gelatin gels and western blot analysis. Gelatin hydrolysis and western blots were compared simultaneously to find out the position of the bands as shown in Fig. 4. Zymogram showed two bands (at $68 \mathrm{kDa}$ and $26.7 \mathrm{kDa}$ ) of gelatin-cleared zones (Fig. 4A, lane 3). These bands were at the same position as the two immuno-reactive bands observed on the western blot using the antisera against CESP2 (Fig. 4B, lane 3). The immuno-blot analysis using the antisera directed against 41.6 kDa polypeptide produced two bands that corresponded to intact CESP and CESP1 (Fig. 4C). But the 41.6 $\mathrm{kDa}$ region was not highlighted by zymogram analysis (Fig. 4A). In the case of CESP from the early Sephadex G 200 gel filtration step, the CESP1 and CESP2 could not be detected (Fig. 4, lanes 1 and 2). These results indicate that the CESP2 even after autolysis still retained the proteolytic

Table 3: Effect of protease inhibitors, metal ions, chelators and sulfhydryl reagents on the activity of the purified CESP

\begin{tabular}{ccccc}
\hline Inhibitor & Conc. $(\mathbf{m M})$ & $\begin{array}{c}\text { Enzyme } \\
\text { Activity (\%) }\end{array}$ & Ions/Complex & $\begin{array}{c}\text { Enzyme } \\
\text { Activity (\%) }\end{array}$ \\
\hline No addition & - & 100 & No addition & 100 \\
\hline TLCK & 0.541 & 0 & Ca & 106 \\
\hline TPCK & 0.568 & 13 & Zn & 115 \\
\hline Antipain & 0.073 & 11 & Cu & 102 \\
\hline Benzamidine & 0.641 & 51 & DTT & 109 \\
\hline PMSF & 1.000 & 57 & $\beta-M E$ & 103 \\
\hline SBTI & 0.0025 & 97 & EDTA & 100 \\
\hline Pepstatin & 0.0364 & 93 & EGTA & 100
\end{tabular}

The enzyme activity of purified CESP was measured in presence of inhibitors using $0.5 \mathrm{mM}$ BAPNA in a reaction mixture $(500 \mu \mathrm{l})$ as described earlier. The $100 \%$ activity is represented by $0.015 \mathrm{EU}$. 


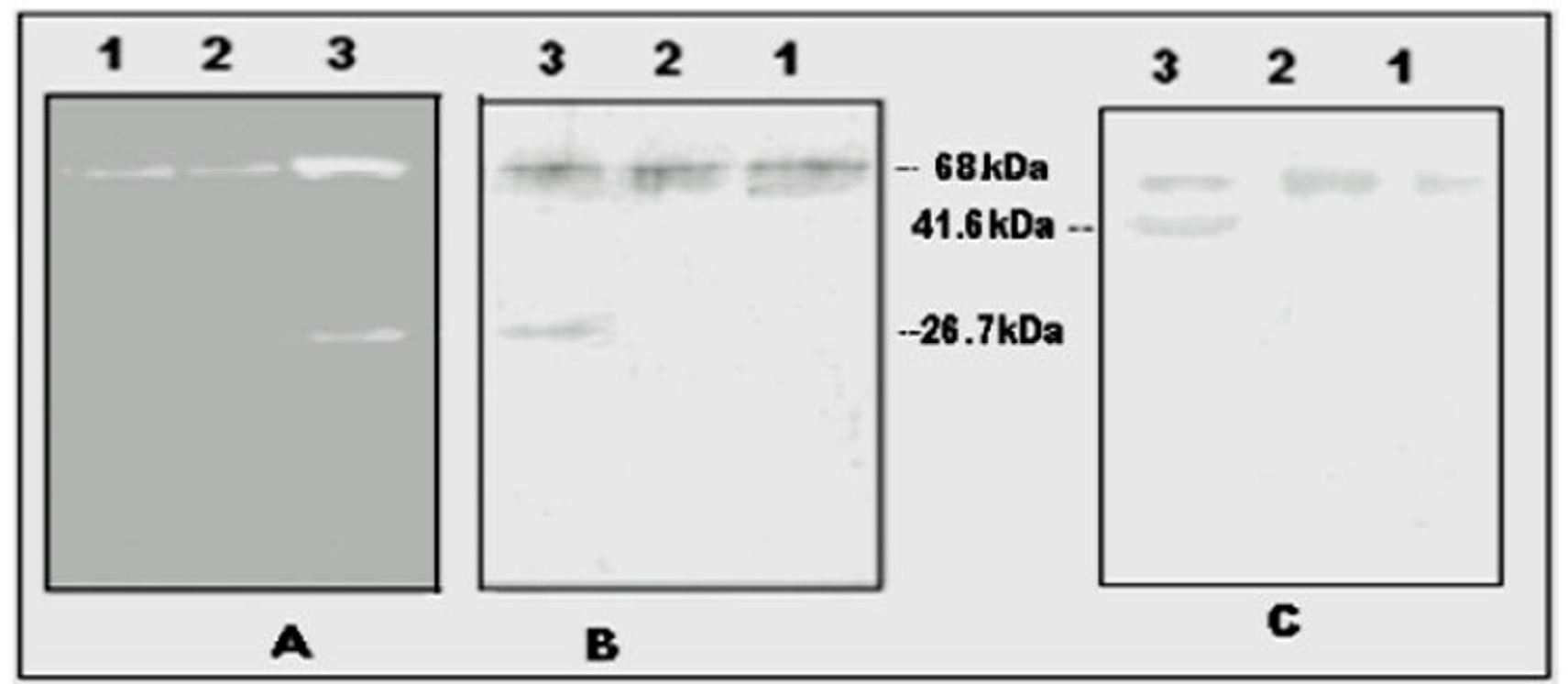

Figure 4

Analysis of the CESP during purification by western blot with the antisera against the $26.7 \mathrm{kDa}$ and $41.6 \mathrm{kDa}$ polypeptide. Comparison of the western blot analysis of the purified CESP with SDS/PAGE zymogram: SDS-PAGE was carried out on gelatin-containing polyacrylamide gel $(12 \%)$ and the gel was cut into two pieces, one was used for zymogram analysis (A). And the other part was electro-transfered to NC membrane. After transfer one part of the membrane was anlysed by western blot with antisera against $26.7 \mathrm{kDa}$ CESP2 (B) and the other part with antisera against $41.6 \mathrm{kDa}$ CESPI polypeptide (C). Lanes: I, Crude extract 2, gel filtration fraction and 3, purified CESP.

activity but the bigger fragment did not exhibit proteolytic activity.

\section{CESP in different varieties of coconut (Cocos nucifera) and distribution during different stages of endosperm development}

The western blot analysis showed that CESP2-antibody recognized the $68 \mathrm{kDa}$ protein in the crude extract prepared from the developing endosperms (Fig. 5A). The increasing amount of CESP in the endosperm during the development from 6 months to maturation supports the result from the previous study [15]. The $68 \mathrm{kDa}$ protein was also present in the crude extracts prepared from all coconut varieties (Fig. 5B). However $26.7 \mathrm{kDa}$ peptide was also detected in these samples which indicate that the enzyme may be degraded during long-term storage of the kernel.

In general the involvement of proteases in the synthesis or degradation of proteins are clear. However, at this point in our studies, we do not know what is the function of CESP. There might be a possibility for a developmental specific function for CESP, as an endopeptidase more likely towards the processing of immature proteins and for the removal of regulatory proteins as and when it is needed during development.

\section{Conclusion}

Identified enzyme (CESP) is a single polypeptide serine protease with approximate molecular mass of $68 \mathrm{kDa}$ and possesses $\mathrm{pH}$ optimum of 8.5 for the hydrolysis of BAPNA. CESP is present in all varieties of coconut studied and in all stages of coconut endosperm development with maximum amount in fully matured coconut. But the physiological role of this alkaline protease is unknown. However, these finding may open up a lot of interest in the involvement of this protease in the area of development or in the storage and shelf life of coconut and its products.

\section{List of abbreviations used}

BAPNA: No-Benzoyl DL-arginine p-nitroanilide; TLCK: No-p-Tosyl-L-Lysine chloromethyl ketone; TPCK: No-pTosyl-L-Phenylalanine chloromethyl ketone; SBTI: Soybean trypsin inhibitor.

\section{Competing interests}

The authors declare that they have no competing interests. 

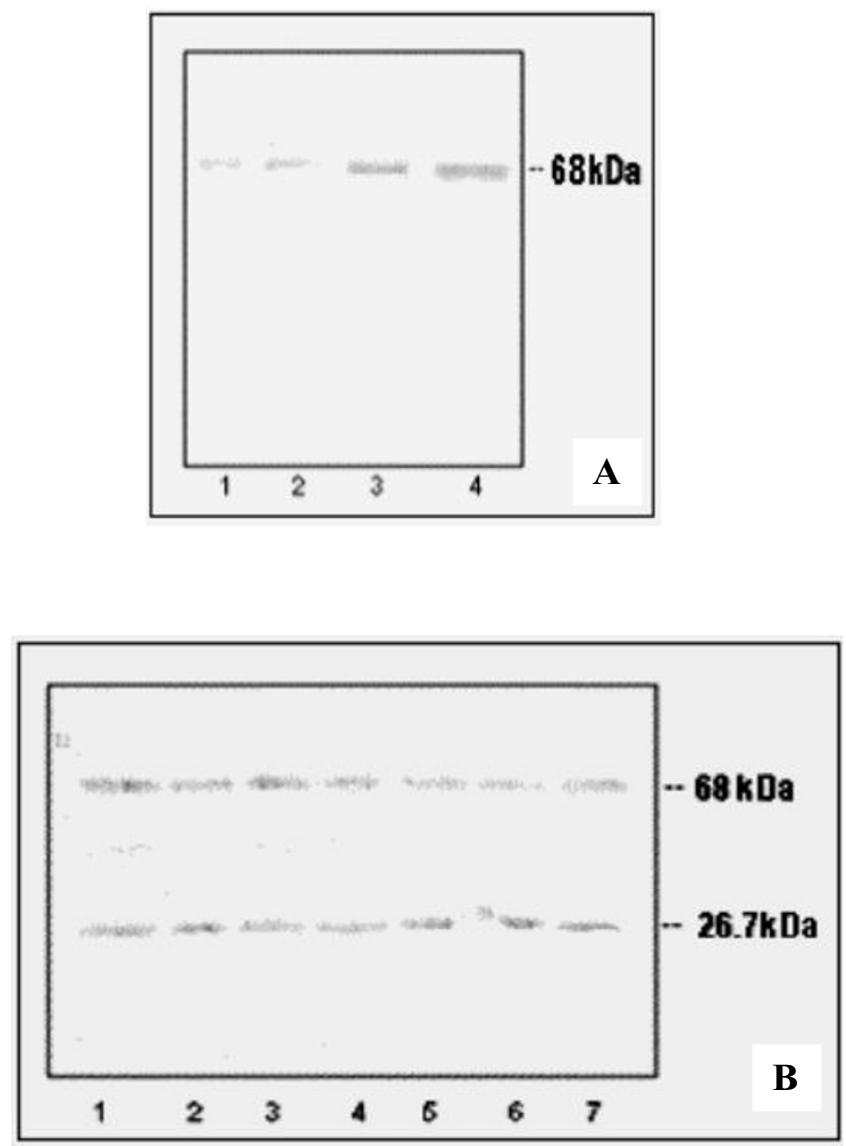

Figure 5

Analysis of CESP for the expression of CESP during coconut maturation and varietal distribution using antiCESP2. (A) Endosperm crude extracts from the coconuts of different stages of development were subjected to western blot analysis. Lanes: I, (6-7) months old coconut; 2, (8-9) months old; 3, (I0-II) months old; 4, fully matured coconut or I2 months old coconut. $3 \mu \mathrm{g}$ of protein loaded in each well. (B) Crude protein extracted from different coconut varieties were subjected to western blot analysis. Coconut varieties used are: Lanes I, Hybrid-TXD; 2, Hybrid DXT; 3, Spikata; 4, Laccadive micro; 5, Chowghat dwarf orange (CDO); 6, Chowghat dwarf green (CDG); 7, West coast tall (WCT).

\section{Authors' contributions}

LMP designed the project, obtained funding support, performed all experiments, data analyzed, manuscript prepared, edited and done revisions. RU contributed to design experiments, data analysis and manuscript preparation. SR contributed to the antibody preparation. CM contributed designing the project, provided funding support, participated in the discussions and manuscript preparation. All authors have read and approved the final manuscript.

\section{Additional material}

\section{Additional File 1}

Purification and characterization of a serine protease (CESP) from mature coconut endosperm. Molecular weight measurement of CESP and characterization of the polyclonal antisera raised in rabbits against CESP1 and CESP2.

Click here for file

[http://www.biomedcentral.com/content/supplementary/17560500-2-81-S1.doc] 


\section{Acknowledgements}

Authors acknowledge the financial support received by LM Panicker from Central Plantation Crops Research Institute (Indian Council of Agricultural Research (ICAR)), Govt. of India.

\section{References}

I. Panicker LM, Usha R, Mandal CN: Protein profiles of Coconut Varieties During Maturation. Plant Archives 2004, 4(I): I87-I89.

2. Muntz K, Belozersky MA, Dunaevsky YE, Schlereth A, Tiedemann J: Stored proteinases and the initiation of storage protein mobilization in seeds during germination and seedling growth. J Exp Bot 2001, 52:1741-1752.

3. Usha R, Singh M: Proteases of germinating winged-bean (psophocarpus tetragonolobis) seeds: Purification and partial characterization of an acidic protease. Biochem $J$ 1996, 3 I 3:423-429.

4. Usha R, Singh M: Purification of a multicatalytic protease complex from developing winged bean seeds by indirect immunoaffinity chromatography. Protein Expression and Purification 1999, 15:48-56.

5. Fontanini D, Jones BL: SEP-I - a subtilisin-like serine endopeptidase from germinated seeds of Hordeum vulgare L. Planta 2002, 2 I 5(6):885-93

6. Timotijevic GS, Radovic SR, Maksimovic VR: Characterization of an aspartic proteinase activity in buckwheat (Fagopyrum esculentum Moench) seeds. I Agric Food Chem 2003, 5 I (7):2100-4.

7. Hara-Nishimura II, Shimada T, Hatano K, Takeuchi $Y$, Nishimura $M$ : Transport of storage proteins to protein storage vacuoles is mediated by large precursor-accumulating vesicles. Plant Cell 1998, I 0(5):825-836.

8. Rasyid F, Hansen PMT: Physiochemical functional and sensory properties of protein extracted from desiccated coconut. CORD 1993, IX(2):

9. Balachandran C: Distribution of major chemical constituents and fatty acids in different regions of coconut endosperm. JAOCS 1985, 62:1583-I586.

10. Balasundaresan D, Sugadev R, Ponnuswamy MN: Purification and crystallization of coconut globulin cocosin from Cocos nucifera. Biochim Biophys Acta 2002, I 60 I(I): I 2 |- I 22.

II. Knutzon DS, Lardizabal KD, Nelsen JS, Bleibaum JL, Davies HM, Metz JG: Cloning of a coconut endosperm cDNA encoding a I-acylsn-glycerol-3-phosphate acyltransferase that accepts medium-chain-length substrates. Plant Physiol 1995, I09(3):999-1006.

12. Islas-Flores II, Oropeza C, Hernandez-Sotomayor SM: Protein phosphorylation during coconut zygotic embryo development. Plant Physiol 1998, I I 8(I):257-63.

13. Manjula C, Chempakam B, Rajagopal V: Physiological and biochemical changes during the germination of coconut seeds. Journal of Plantation Crops 1993, 2 I (supplement):313-321.

14. Nagarajan M, Pandalai KM: Studies on the enzyme activity in the haustorium of germinating coconut. Indian coconut journal 1963 , I 7:25-34.

15. Panicker LM, Usha R, Mandal CN: Variation of protease activity in coconut kernel in relation to variety, nut maturity and season. CORD 2005, 2 I(2): I3-I7.

16. Ouchterlony $O$ : In vitro method for testing the toxin-producing capacity of Diphtheria bacteria. Acta Pathol Microbiol Scand 1948, 25:186-191.

17. Towbin H, Staehlin T, Gordon J: Electrophoretic transfer from polyacrylamide gels to nitrocellulose sheets: Procedures and some applications. Proc Natl Acad Sci USA 1979, 76:4350-4354.

18. Laemmli UK: Cleavage of structural proteins during the assembly of the head of Bacteriophage T4. Nature 1970, 227:680-685.

19. Heussen C, Dowdle EB: Electrophoretic analysis of plasminogen activators in polyacrylamide gels containing sodium dodecyl sulfate and copolymerised substrates. Analytical Biochemistry 1980, 102:196-202.

20. Bradford MM: A rapid and sensitive method for the quantitation of microgram quantities of protein utilizing the principle of protein-dye binding. Analytical Biochemistry 1976, 72:248-254.
21. Wilchek M, Miron T, Kohn J: Affinity chromatography. Methods Enzymol 1984, 104:3-55.

22. Vierstra RD: Proteolysis in plants: mechanisms and functions. Plant Molecular Biology 1996, 32:275-302.

23. Runeberg-Roos P, Sarma M: Phytepsin, a barley vacuolar aspartic proteinase, is highly expressed during autolysis of developing tracheary elements and sieve cells. Plant J 1998 , I 5: 139-45.

24. Yamagata $\mathrm{H}$, Ueno $\mathrm{S}$, Iwasaki $\mathrm{T}$ : Isolation and characterization of possible native cucumisin from developing melon fruits. And its limited autolysis to cucumisin. Agric Biol Chem 1989, 53:1009-1017.

25. Uchikoba T, Yonezawa H, Kaneda M: Cucumisin like protease from the sarcocarp of Benincasa hispida var Ryukyu. Phytochemistry 1998, 49:2215-2219.

26. Sutoh K, Kato H, Minamikawa T: Identification and possible roles of three types of endopeptidase from germinated wheat seeds. I Biochem 1999, I 26:700-707.

27. Arima K, Uchikoba T, Shimada M, Yonezawa H, Shimada M, Keneda $M$ : Cucumisin-like protease from the latex of Euphorbia supina. Phytochemistry 2000, 53:639-644.

28. Demartini DR, Wlodawer A, Carlini CR: A comparative study of the expression of serine proteinases in quiescent seeds and in developing Canavalia ensiformis plants. Journal of Experimental Botany 2007, 58:521-532.

29. Yonezawa H, Kaneda M, Uchikoba T: Substrate specificity of honeydew melon protease $D$, a plant serine endopeptidase. Biosci Biotechnol Biochem 1997, 6 I:I277-1280.

Publish with Bio Med Central and every scientist can read your work free of charge

"BioMed Central will be the most significant development for disseminating the results of biomedical research in our lifetime. "

Sir Paul Nurse, Cancer Research UK

Your research papers will be:

- available free of charge to the entire biomedical community

- peer reviewed and published immediately upon acceptance

- cited in PubMed and archived on PubMed Central

- yours - you keep the copyright

BioMedcentral 